\title{
Lipoprotein Lipase Modulates Net Secretory Output of Apolipoprotein B In Vitro A Possible Pathophysiologic Explanation for Familial Combined Hyperlipidemia
}

Kevin Jon Williams," Kelly A. Petrie, ${ }^{*}$ Robert W. Brocia, ${ }^{*}$ and Theresa L. Swenson*

*Department of Physiology and Biochemistry, The Medical College of Pennsylvania, Philadelphia, Pennsylvania 19129; and ${ }^{\ddagger}$ Merck Sharp \& Dohme Research Laboratories, Rahway, New Jersey 07065

\begin{abstract}
We showed previously that net secretory output of apolipoprotein B (apo B) from cultured human hepatoma cells (HepG2) is regulated by rapid reuptake of nascent lipoproteins before they have diffused away from the vicinity of the cells. We now sought to determine if the nascent lipoproteins could be remodeled to enhance or impede reuptake. We found that lipoprotein lipase (LpL), an enzyme that hydrolyzes lipoprotein triglyceride, reduced HepG2 output of apo B to one-quarter to one-half of control. The reduction was apparent during co-incubations as short as $2 \mathrm{~h}$ and as long as $24 \mathrm{~h}$. Heparin, which blocks receptor-mediated binding of lipoproteins, abolished the effect of LpL on apo B output, without causing enzyme inhibition. To assess uptake directly, we prepared labeled nascent lipoproteins. LpL tripled the cellular uptake of labeled nascent lipoproteins, from $15.2 \% \pm 0.7 \%$ to $48.7 \% \pm 0.3 \%$ of the total applied to the cells. Cellular uptake of ${ }^{125}$ I-labeled anti-LDL receptor IgG was unaffected by $L p L$; thus, $L p L$ enhanced reuptake by altering lipoproteins, not receptors. Because $\mathrm{LpL}$ is present in the space of Disse in the liver, we conclude that $L p L$ may act on newly secreted lipoproteins to enhance reuptake in vivo. $L p L$ deficiency would reduce local reuptake of apo $B$, which would appear as overproduction, thereby providing a mechanistic link between partial LpL deficiency and familial combined hyperlipidemia. (J. Clin. Invest. 1991. 88:1300-1306.) Key words: fibric acid • futile cycling • heparin • hepatoma $G 2$ cell $~$ space of Disse
\end{abstract}

\section{Introduction}

Apolipoprotein B-100 (apo B) is a 550-kD glycoprotein that is an essential component of low-density lipoproteins (LDL) and very low-density lipoproteins (VLDL) and has been implicated in the development of coronary artery disease. In humans, apo B is made by the liver, but mechanisms of secretory control have been poorly understood.

We recently showed that net secretory output of apo B from human hepatoma G2 (HepG2) ${ }^{1}$ cells in culture can be regu-

A preliminary report of this study was presented at the 63rd Scientific Sessions of the American Heart Association, Dallas, TX, 13 November 1990 (1).

Address reprint requests to Dr. Williams, Department of Physiology \& Biochemistry, Medical College of Pennsylvania, 3300 Henry Avenue, Philadelphia, PA 19129. 1991.

Received for publication 26 March 1991 and in revised form 18 June

1. Abbreviations used in this paper: HepG2, human hepatocellular carcinoma G2; LpL, lipoprotein lipase; PTA, phosphotungstic acids.

J. Clin. Invest.

(c) The American Society for Clinical Investigation, Inc.

0021-9738/91/10/1300/07 $\$ 2.00$

Volume 88, October 1991, 1300-1306 lated by rapid reuptake of nascent lipoproteins shortly after their export across the plasma membrane (2). Thus, a variety of stimuli affects the net output of apo $B$, such as altering the number of cellular LDL receptors $(2,3)$ or altering the rate of diffusion out of the unstirred water layer by changing the viscosity of the culture medium $(2,4)$.

We now sought additional factors that might modulate net cellular output of apo B by enhancing or impeding reuptake. Several factors have been reported to affect the binding of mature plasma lipoproteins to the cell surface, and might therefore affect the binding and reuptake of apo B-rich nascent particles. These factors include lipoprotein lipase $(\mathrm{LpL})(5-10)$, hepatic lipase $(5,10,11)$, phospholipase $A_{2}(12,13)$, cholesteryl ester transfer protein $(11,14)$, lecithin: cholesterol acyl transferase (15), lysophosphatidylcholine (16), apo E (17-19), apo AIV (20), and the C-apoproteins $(21,22)$.

For several reasons, we began our investigations with $\mathrm{LpL}$. First, it is present in and near the space of Disse in adult mammalian liver (23). Thus, it would have physical access to newly secreted hepatic lipoproteins. Second, its enzymatic action on mature, triglyceride-rich lipoproteins is rapid (24), suggesting that it could substantially remodel nascent particles before they have diffused away from the vicinity of the hepatocytes. Third, LpL has been documented to enhance receptor binding and cellular uptake of a very broad range of apo B-containing lipoproteins, including LDL (5), VLDL $(6,7), \beta$-VLDL (8), and chylomicrons $(9,10)$. Finally, we hypothesized a physiologic link between $\mathrm{LpL}$ and apo B secretion (1), based on the recent finding of partial LpL deficiency in some cases of familial combined hyperlipidemia $(25,26)$, a disease of hepatic apo B overproduction (27).

\section{Methods}

Purification of $L p L$. LpL (EC 3.1.1.34) was purified from fresh cow's milk by a modification of the method of Posner et al. (28). The cream, which contains no detectable $\mathrm{LpL}$ activity, was removed from fresh milk by centrifugation $(22,000 \mathrm{~g}$ for $75 \mathrm{~min})$ and discarded. $10 \mathrm{ml}$ of Intralipid (Kabi-Vitrum, Alameda, CA) was added per $210 \mathrm{ml}$ of skim milk, and the mixture was incubated for $30 \mathrm{~min}$ at $37^{\circ} \mathrm{C}$ on a shaker. The Intralipid, which binds $\mathrm{LpL}$, was recovered and washed by two centrifugations at $3,300 \mathrm{~g}$ for $60 \mathrm{~min}$ at $4^{\circ} \mathrm{C}$ in a SW 28 rotor (Beckman Instruments, Inc., Somerset, $\mathrm{NJ}$ ). The final floating fat cakes were recovered with the use of a spatula and suspended in cold acetone $(80 \mathrm{ml}$ per cake), filtered on a medium-porosity sintered glass funnel, and delipidated with diethyl ether washes ( $50 \mathrm{ml}$ per cake). The resulting powder is a partially purified preparation of $\mathrm{LpL}$ that is stable at $-20^{\circ} \mathrm{C}$ for several months (28).

Before each experiment, a fresh batch of highly purified $\mathrm{LpL}$ was prepared by subjecting a portion of the acetone powder to heparinagarose chromatography (Affi-gel heparin, Bio-Rad Laboratories, Richmond, CA) (28). The acetone powder was suspended by end-overend rotation in $0.1 \%$ Triton X-100 in standard buffer $\left(50 \mathrm{mM} \mathrm{NH}_{4} \mathrm{OH}-\right.$ $\mathrm{HCl}, \mathrm{pH} 8.5$ ) at a concentration of $6.25 \mathrm{mg}$ of powder per $\mathrm{ml}$. It was 
then applied to the column equilibrated in standard buffer, at $4.0 \mathrm{ml}$ of suspension per $\mathrm{ml}$ of wet gel. The column was washed with $0.3 \mathrm{M} \mathrm{NaCl}$, $0.2 \mathrm{M}$ sodium citrate in standard buffer, followed by $0.72 \mathrm{M} \mathrm{NaCl}$ in standard buffer. Pure $\mathrm{LpL}$ was eluted with $2.0 \mathrm{M} \mathrm{NaCl}$ in standard buffer, then simultaneously concentrated and dialyzed into $10 \mathrm{mM}$ sodium phosphate, $150 \mathrm{mM} \mathrm{NaCl}, \mathrm{pH} 7.40$, using a YM30 membrane (Amicon Corp., Lexington, MA). The final enzyme preparation was adjusted to $30 \%$ glycerol and stored at $-20^{\circ} \mathrm{C}$ until use.

By polyacrylamide gel electrophoresis in sodium dodecyl sulfate and mercaptoethanol (29), there was a single band at 58,000 D. Lipase activity was measured using Intralipid labeled with glycerol tri $[9,10(\mathrm{n})$ ${ }^{3} \mathrm{H}$ ]oleate as the substrate (Amersham Corp., Arlington Heights, IL) (30) and apo-HDL as a source of apo CII. The reaction mixture (200 $\mu \mathrm{l})$ was incubated at for $15 \mathrm{~min}$ at $25^{\circ} \mathrm{C}$, and the reaction was terminated by the addition of $3.25 \mathrm{ml}$ of methanol/chloroform/heptane $(1.41: 1.25: 1.00, \mathrm{vol} / \mathrm{vol} / \mathrm{vol})$, followed by $1.05 \mathrm{ml}$ of potassium carbonate buffer (pH 10 Buffer Standard Solution, Fisher Scientific Co., Malvern, PA) (31). Release of $\left[{ }^{3} \mathrm{H}\right]$ oleate was determined by liquid scintillation counting of the top (aqueous) phase. Specific activities at $25^{\circ} \mathrm{C}$ for our preparations were $118.0 \pm 16.6 \mathrm{U} / \mathrm{mg}$ (mean $\pm \mathrm{SEM}, n=5$ ), where 1 $\mathrm{U}$ was defined as the amount of $\mathrm{LpL}$ that released $1 \mu \mathrm{mol}$ of free fatty acid per minute.

Apo B secretion experiments. In our secretion experiments, HepG2 cells grown to near-confluency in $35-\mathrm{mm}$ wells were incubated overnight in a selenium-supplemented, serum-free medium that sustains their usual rate of growth, as described previously (2). The next morning, the cells received fresh medium supplemented with $L-[4,5$ ${ }^{3} \mathrm{H}$ lleucine (120-190 Ci/mmol, Amersham Corp., $75 \mu \mathrm{Ci} / \mathrm{ml}$ of medium, $1.0 \mathrm{ml}$ of medium per $35-\mathrm{mm}$ well), with or without the highly purified bovine milk LpL. Buffer with $30 \%$ glycerol was added to all control wells, to match the volume of $\mathrm{LpL}$. After incubation for 2-24 h at $37^{\circ} \mathrm{C}$, media and cells were harvested.

Tritiated apo B was purified from media either by immunoprecipitation or by ultracentrifugation followed by precipitation in $50 \%$ isopropanol. Immunoprecipitation was performed by an adaptation of the procedures of Harlow and Lane (32), using a monospecific rabbit anti-human apo B antiserum that was generously supplied by Dr. Charles L. Bisgaier, Columbia University (33). Samples of media (300$500 \mu \mathrm{l}$ ) were mixed with a detergent solution to achieve final concentrations of $1.25 \%$ Triton $X-100$ and $0.625 \%$ sodium dodecyl sulfate, then incubated overnight at $4^{\circ} \mathrm{C}$ to solubilize the apo $\mathrm{B}$ completely. A mock immunoprecipitation was performed by adding $5 \mu \mathrm{l}$ of nonimmune serum and $40 \mu \mathrm{l}$ of protein A-Sepharose beads (catalogue no. P-3391, Chemical Co., St. Louis, MO) to each sample and incubating for $1 \mathrm{~h}$ at room temperature. After removing the protein A beads by centrifugation, a true immunoprecipitation was performed by adding $5 \mu \mathrm{l}$ of immune serum, followed by a $1-\mathrm{h}$ incubation at room temperature, addition of another $40 \mu \mathrm{l}$ of protein $A$ beads, then another 1-h incubation. The second set of protein A beads was washed 10 times with a solution of Triton X-100 and sodium dodecyl sulfate, and near-absence of radioactivity in the final wash was verified by scintillation counting ( $<20 \mathrm{cpm}$ above background). Bound immune complexes were released from the beads by adding $500 \mu l$ of release buffer (2\% sodium dodecyl sulfate, $60 \mathrm{mM}$ Tris, $10 \%$ glycerol, $\mathrm{pH} 6.8$ ) and incubating for $10 \mathrm{~min}$ at $80^{\circ} \mathrm{C}(32)$. Released radioactivity was measured by liquid scintillation counting.

Quantitative and specific immunoprecipitation was verified in several ways. First, samples of unlabeled conditioned medium were mixed with ${ }^{125} \mathrm{I}-\mathrm{LDL}$, then subjected to immunoprecipitation, to verify that antiserum was added in excess of antigen, and that protein $A$ beads were added in excess of antiserum (32). We achieved $92.0 \% \pm 0.6 \%$ (mean \pm SEM, $n=10$ ) recovery of ${ }^{125}$ I-LDL. Second, samples of labeled conditioned medium were removed from cells, incubated at $37^{\circ} \mathrm{C}$ for 2-24 h with or without $\mathrm{LpL}$, and then immunoprecipitated. These studies showed that $\mathrm{LpL}$ had no effect on $\left[{ }^{3} \mathrm{H}\right]$ apo B recovery (decreased by $3.3 \% \pm 2.0 \%, n=3$, NS). Incubation with $\mathrm{LpL}$ also had no effect on immunoprecipitation of ${ }^{125}$ I-LDL that had been added to unlabeled conditioned medium (increased by $1.6 \% \pm 0.7 \%, n=4$, NS).
Finally, selected immunoprecipitates from experimental incubations were subjected to polyacrylamide gel electrophoresis and autoradiography, to verify the identity of the preciptated radioactivity as $\left[{ }^{3} \mathrm{H}\right]$ apo $B$ (see Results section).

Purification of tritiated apo B from media by ultracentrifugation and isopropanol precipitation was performed by the method of Egusa et al. (34), with minor modifications as previously described (2). Specifcally, media samples were each supplemented with $\sim 200 \mu \mathrm{g}$ of carrier LDL protein. The ultracentrifugation was performed at a density of $1.21 \mathrm{~g} / \mathrm{ml}$, to ensure total recovery of all lipoproteins. The ultracentrifugation supernatants were then mixed with distilled water, to lower the density to $1.063 \mathrm{~g} / \mathrm{ml}$ before addition of isopropanol to precipitate apo B at $4^{\circ} \mathrm{C}$ (cf. reference 34 ).

Total secreted ${ }^{3} \mathrm{H}$-protein was measured by liquid scintillation counting of the washed pellet obtained from precipitation of media with $10 \%(\mathrm{wt} / \mathrm{vol})$ trichloroacetic acid and $1.0 \%$ (wt/vol) phosphotungstic acid (TCA/PTA) (35). Total cellular protein was determined by modified Lowry (36). Data for apo B output by the cells were expressed either as the percentage of total labeled secreted protein that was labeled apo B (i.e., 100 times $\left[{ }^{3} \mathrm{H}\right]$ apo $\mathrm{B}$ radioactivity divided by ${ }^{3} \mathrm{H}$-protein radioactivity), or as total $\left[{ }^{3} \mathrm{H}\right]$ apo $B$ radioactivity secreted per well.

In one secretion experiment, heparin $(20 \mathrm{mg} / \mathrm{ml}$; catalogue no. H-3125, lot no. 29F-0314; Sigma Chemical Co.) was added simultaneously with the $\left[{ }^{3} \mathrm{H}\right]$ leucine and $\mathrm{LpL}$, to block receptor-mediated reuptake of nascent lipoproteins $(37,38)$. Media were harvested $2 \mathrm{~h}$ later for determination of secreted $\left[{ }^{3} \mathrm{H}\right]$ apo $\mathrm{B}$ and total ${ }^{3} \mathrm{H}$-protein.

Apo B uptake experiments. In our experiments to examine uptake of lipoproteins by HepG2 cells directly, we prepared ${ }^{3} \mathrm{H}$-labeled nascent lipoproteins, ${ }^{125} \mathrm{I}$-labeled LDL, and ${ }^{125}$ I-labeled monoclonal antiLDL receptor IgG. ${ }^{3} \mathrm{H}$-labeled nascent lipoproteins were prepared by incubating one set of HepG2 cells with $\left[{ }^{3} \mathrm{H}\right]$ leucine in serum-free medium overnight. Media were harvested, pooled, and the $d<1.063 \mathrm{~g} / \mathrm{ml}$ fraction was isolated (39), without the addition of carrier lipoproteins. Excess salt and $\left[{ }^{3} \mathrm{H}\right] l$ leucine were removed by dialysis. By electrophoresis in sodium dodecyl sulfate, autoradiography, and laser densitometry, the distribution of label among the apoproteins was $73.2 \%$ apo B, $3.7 \%$ apo E, and $23.1 \%$ apo AI. These labeled nascent lipoproteins were placed onto a second set of HepG2 cells at $5 \mu \mathrm{g}$ of lipoprotein protein/ $\mathrm{ml}$, with or without $\mathrm{LpL}$, and incubated for $5 \mathrm{~h}$. Incubations were performed in the presence of $10 \mathrm{mM}$ unlabeled leucine, to reduce recycling of label (40). Cellular removal of labeled nascent lipoproteins from the media was assessed by measuring TCA-precipitable ${ }^{3} \mathrm{H}$ (i.e., ${ }^{3} \mathrm{H}$-apoproteins) remaining in the media and by measuring total ${ }^{3} \mathrm{H}$ radioactivity accumulated by the cells.

${ }^{125}$ I-Labeled LDL and ${ }^{125}$ I-labeled anti-LDL receptor IgG were prepared by radioiodination by the iodine monochloride method $(41,42)$. The LDL was from a fasted, normolipidemic woman. The anti-LDL receptor IgG was produced from a hybridoma obtained from the American Type Culture Collection, Rockville, MD (catalogue no. CRL 1691) $(43,44)$. The two labeled proteins were placed onto HepG2 cells at a concentration of $18 \mathrm{nM}$, and incubated for $5 \mathrm{~h}$ with or without LpL. Incubations in wells without cells were conducted in parallel. Cellular uptake of ${ }^{125}$ I-proteins was assessed as ${ }^{125}$ I-radioactivity in cells after scraping and rinsing. Cellular degradation of ${ }^{125}$ I-proteins was assessed as TCA-soluble, chloroform-insoluble ${ }^{125}$ I-radioactivity in the media (42). Degradation in cell-free wells was $<3 \%$ of the degradation in the presence of cells, and was unaffected by $\mathrm{LpL}$.

Statistics. Results are given as mean \pm SEM. Statistical comparisons were performed by Student's two-tailed $t$ test.

\section{Results}

Our preliminary experiments indicated that $\mathrm{LpL}$ reduced the net secretory output of $\left[{ }^{3} \mathrm{H}\right]$ apo B from HepG2 cells to $22.5 \% \pm 0.6 \%$ of control $(n=4, P<0.00005)$ (1). We sought to characterize this effect more completely.

Fig. 1 demonstrates that the output of $\left[{ }^{3} \mathrm{H}\right]$ apo $B$ from 


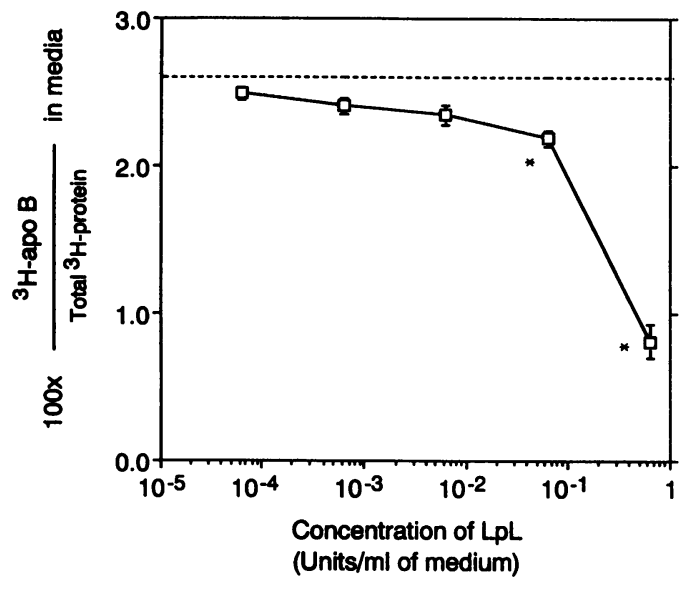

Figure 1. Dose response of LpL-mediated reduction in $\left[{ }^{3} \mathrm{H}\right]$ apo $B$ output by HepG2 cells. HepG2 cells were incubated for $2 \mathrm{~h}$ in media supplemented with $75 \mu \mathrm{Ci}$ of $\left[{ }^{3} \mathrm{H}\right]$ leucine $/ \mathrm{ml}, 0-0.640 \mathrm{U}$ of bovine milk $\mathrm{LpL}$ per $\mathrm{ml}$, and buffer to equalize volumes. Secreted $\left[{ }^{3} \mathrm{H}\right]$ apo $B$ was purified from the $d<1.21 \mathrm{mg} / \mathrm{ml}$ fraction of media by precipitation in 50\% isopropanol. Total secreted ${ }^{3} \mathrm{H}$-protein was purified from media by TCA/PTA precipitation. The dashed line indicates cellular output of apo B in the absence of added LpL. The solid line indicates output in the presence of the indicated concentrations of $\mathrm{LpL}$ activity. Displayed are means \pm SEM, $n=4$. Asterisks indicate outputs signifcantly different from the no-LpL control $(P<0.01)$. Cellular output of total ${ }^{3} \mathrm{H}$-protein was not significantly affected by $\mathrm{LpL}$.

HepG2 cells during a 2-h incubation is dose responsive to the addition of increasing amounts of LpL. At 0.064-0.640 U $\mathrm{LpL} / \mathrm{ml}$, the reduction in $\left[{ }^{3} \mathrm{H}\right]$ apo B output was large and statistically significant. At low concentrations of added $\mathrm{LpL}$, there was a consistent trend toward reduced $\left[{ }^{3} \mathrm{H}\right] \mathrm{apo}$ B output. Cellular output of total ${ }^{3} \mathrm{H}$-protein was not significantly affected at any $\mathrm{LpL}$ concentration.

The top panel of Fig. 2 shows the time course of $\left[{ }^{3} \mathrm{H}\right]$ apo B output in the presence and absence of added $\mathrm{LpL}$. The reduction in output caused by addition of $\mathrm{LpL}$ was rapid in onset and sustained throughout the 24-h incubation. The degree of reduction was fairly constant for the first $12 \mathrm{~h}$ after addition of $\mathrm{LpL}$. Between 12 and $24 \mathrm{~h}$, however, the effect of $\mathrm{LpL}$ on the apo B secretory rate was somewhat less pronounced. This might be the result of loss of enzymatic activity with time or suppression of cellular $\mathrm{LDL}$ receptors. As before, $\mathrm{LpL}$ had no effect on the secretory output of total ${ }^{3} \mathrm{H}$-protein (Fig. 2, bottom).

To determine the mechanism of the reduction in apo B output, we directly blocked reuptake by the HepG2 cells of their own secreted particles (Fig. 3). Blockage of receptor-mediated uptake with heparin abolished the ability of $\mathrm{LpL}$ to reduce apo B output. In the absence of heparin, the output of apo B from LpL-supplemented cells was $56.3 \% \pm 1.5 \%$ less than the output from nonsupplemented cells. In the presence of heparin, however, the output from LpL-supplemented cells was slightly higher than the output from nonsupplemented cells, though not significantly. In separate studies, we found that this concentration of heparin had no inhibitory effect on the enzymatic activity of our preparations of $\mathrm{LpL}$, consistent with several prior reports (reviewed in reference 24). Thus, these results indicate that essentially all of the difference in apo B output caused by $\mathrm{LpL}$ depends on receptor-mediated reuptake. With
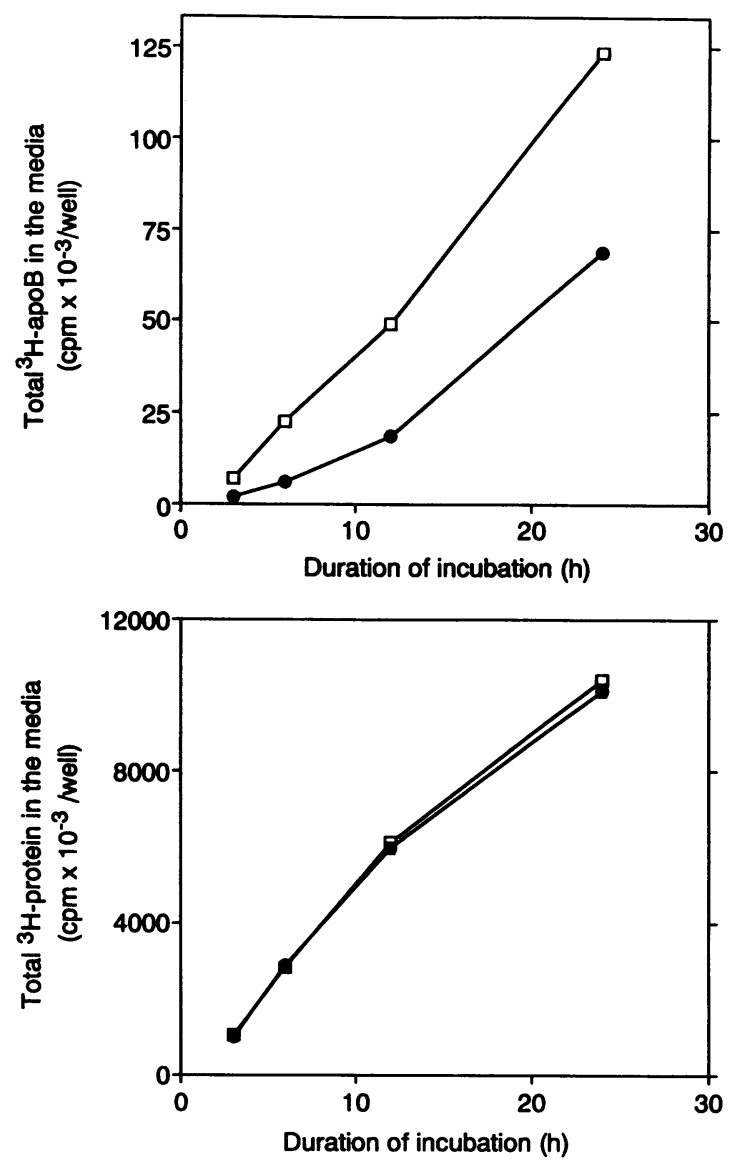

Figure 2. Time course of cellular output of $\left[{ }^{3} \mathrm{H}\right]$ apo B and total ${ }^{3} \mathrm{H}$ protein in the presence and absence of LpL. At $t=0 \mathrm{~h}, \mathrm{HepG} 2$ cells were given $\left[{ }^{3} \mathrm{H}\right]$ leucine, with (solid symbols) or without (open symbols) $0.640 \mathrm{U} \mathrm{LpL} / \mathrm{ml}$. Media and cells were harvested at the indicated times. The top panel displays the outputs of $\left[{ }^{3} \mathrm{H}\right]$ apo $\mathrm{B}$, which was purified from media by immunoprecipitation, and its identity verified by polyacrylamide gel electrophoresis and autoradiography. The bottom panel displays the outputs of total secreted ${ }^{3} \mathrm{H}$-protein, which was purified from media by TCA/PTA precipitation. Means are shown, $n=4$. SEMs were smaller than the graphic symbols. The output of $\left[{ }^{3} \mathrm{H}\right]$ apo $B$ at each time point was significantly reduced by LpL $(P<0.00005)$. Outputs of ${ }^{3} \mathrm{H}$-protein were unaffected by LpL.

or without $\mathrm{LpL}$, heparin raised the net cellular output of $\left[{ }^{3} \mathrm{H}\right]$ apo $B$ to $46-55 \%$ above the no-LpL, no-heparin control. This result confirms that there is substantial reuptake of nascent lipoproteins even in the absence of added LpL, consistent with previous results (2). In the presence of $L p L$, our results indicate that most apo B exported across the plasma membrane is taken back up (compare second and fourth columns in Fig. 3).

To verify directly that $\mathrm{LpL}$ enhances uptake of nascent lipoproteins by HepG2 cells, we incubated HepG2 cells for $5 \mathrm{~h}$ with ${ }^{3} \mathrm{H}$-labeled nascent lipoproteins, in the presence or absence of added LpL. The loss of TCA-precipitable radioactivity from the medium tripled, from $15.2 \% \pm 0.7 \%$ without $\mathrm{LpL}$ to $48.7 \% \pm 0.3 \%$ with LpL $(n=5, P<0.00005)$ (Fig. 4, top). Lipoprotein lipase caused a corresponding threefold increase in the cellular accumulation of radioactivity (Fig. 4, bottom).

Finally, we sought to determine if LpL-induced enhancement of cellular uptake of lipoproteins results from alterations 


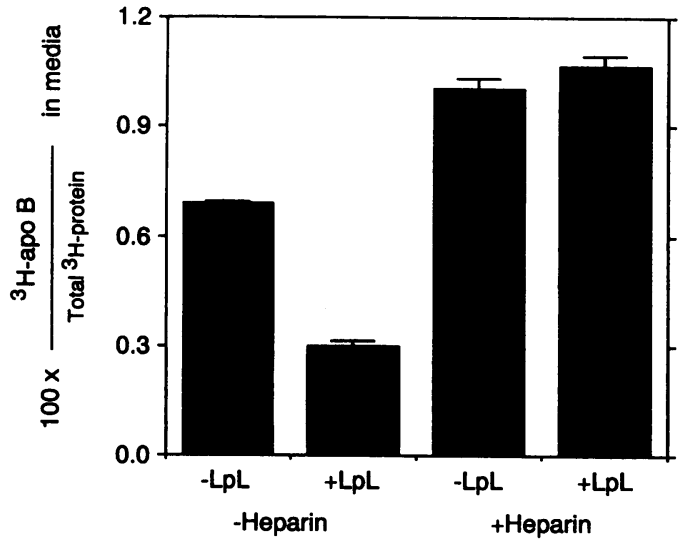

Figure 3. Effect of heparin and $\mathrm{LpL}$ on the output of newly synthesized apo B from HepG2 cells. HepG2 cells were incubated for $2 \mathrm{~h}$ with $\left[{ }^{3} \mathrm{H}\right]$ leucine, with or without $\mathrm{LpL}(0.640 \mathrm{U} / \mathrm{ml})$, with or without heparin $(20 \mathrm{mg} / \mathrm{ml})$, as indicated. $\left[{ }^{3} \mathrm{H}\right]$ apo $B$ was then isolated from media by isopropanol precipitation; essentially identical quantitative results were obtained in a separate experiment using apo B immunoprecipitation. ${ }^{3} \mathrm{H}$-protein was isolated by TCA/PTA precipitation. Displayed are outputs of labeled apo $B$ as a percentage of total labeled secreted protein. Means \pm SEM are shown, $n=5$. The three columns to the right are each significantly different from the leftmost column $(P<0.00005)$. The two columns labeled " + Heparin" are not significantly different from each other.

in the lipoproteins or in cellular LDL receptors. Two ligands for the LDL receptor were used: mature plasma LDL and a monoclonal anti-LDL receptor $\operatorname{IgG}(43,44)$. $L D L$ is a substrate for $\mathrm{LpL}(5)$, whereas the IgG is not. Both ligands were radioiodinated, then separately incubated with HepG2 cells for $5 \mathrm{~h}$, with and without $\mathrm{LpL}$.

Lipoprotein lipase substantially increased uptake and degradation of ${ }^{125}$ I-LDL by HepG2 cells (cf. reference 5), but had no effect on uptake or degradation of the ${ }^{125}$ I-labeled anti-LDL receptor IgG (Fig. 5). Thus, LpL enhances uptake of lipoproteins by altering the lipoproteins, without altering cellular receptors, consistent with previous reports $(5,11)$.

\section{Discussion}

Our results indicate that $\mathrm{LpL}$ substantially reduces the net secretory output of apo B from HepG2 cells. This reduction is primarily due to an enhancement of cellular reuptake of newly secreted lipoproteins. In the presence of $\mathrm{LpL}$, the vast majority of apo B exported out of the cell is taken back up. The enhancement of reuptake is the result of alterations in the lipoproteins that lead to enhanced cell-surface binding, similar to effects previously described for apo B-rich lipoproteins from plasma (5-10).

The direct physiologic importance of our findings depends on the presence of $\mathrm{LpL}$ in the liver, particularly near sites of lipoprotein secretion and LDL receptor expression. Although LpL has generally been regarded as an extrahepatic enzyme, recent work indicates that it can be present in the liver in large amounts (reviewed in reference 23), including in adult mammalian liver $(23,30,45-48)$.

There are two possible sources for intrahepatic LpL. First, it could be synthesized locally, either by hepatic parenchymal cells $(49-51)$ or by macrophages $(52,53)$ within the liver. The second possibility, for which more evidence exists in the adult
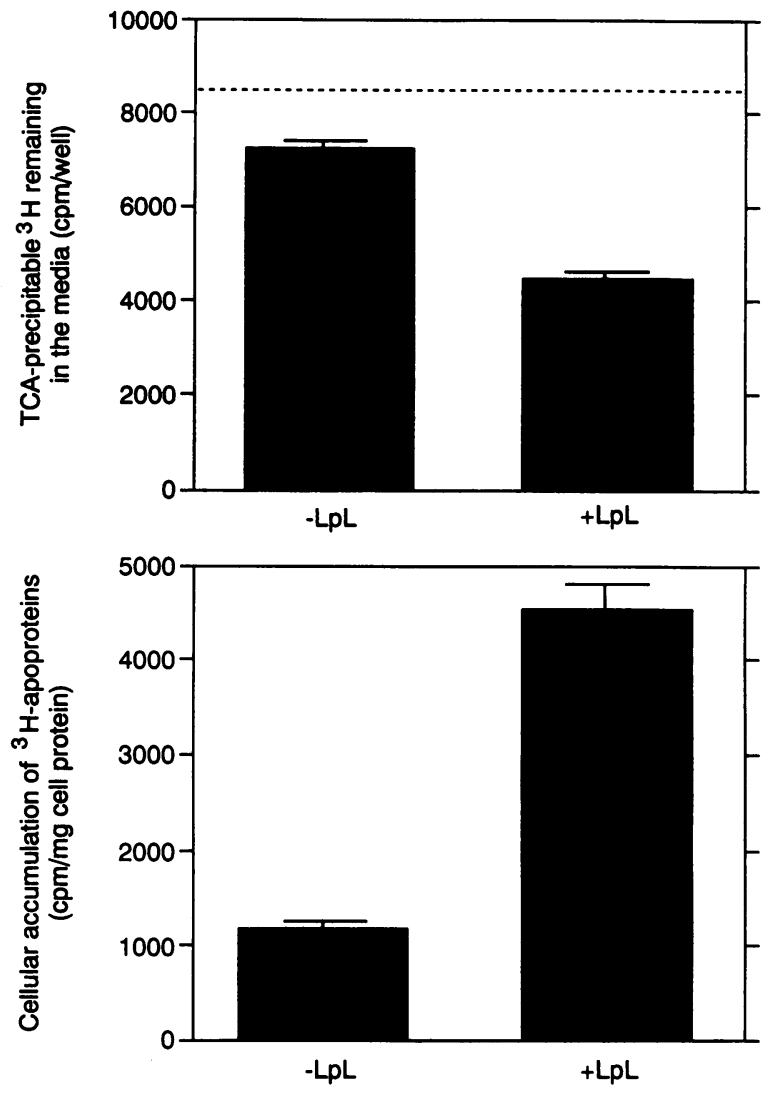

Figure 4. Effect of LpL on cellular uptake of nascent lipoproteins from the bulk fluid phase of media. Labeled, nascent lipoproteins ( 5 $\mu \mathrm{g} / \mathrm{ml})$ were incubated with HepG2 cells, with or without $\mathrm{LpL}(0.640$ $\mathrm{U} / \mathrm{ml}$ ), as indicated. After $5 \mathrm{~h}$, media and cells were harvested. The top panel displays TCA/PTA-precipitable radioactivity remaining in the media. The dashed line indicates TCA/PTA-precipitable radioactivity in the media before the 5-h incubation. The bottom panel displays cellular accumulation of ${ }^{3} \mathrm{H}$ from labeled apoproteins.

Means \pm SEM are shown, $n=5$. Average cellular protein mass was $0.973 \mathrm{mg}$ per $35-\mathrm{mm}$ well.

mammal, is that $\mathrm{LpL}$ is transported from its major sites of synthesis in extrahepatic tissues to the liver. Hepatic uptake of $\mathrm{LpL}$ from the circulation has been directly demonstrated $(30$, 54), and this LpL remains enzymatically active intrahepatically (55). Transport from extrahepatic tissues to the liver can be enhanced by a fatty meal (30) or by injection of Intralipid $(23,30,48)$. Most importantly, intrahepatic LpL is located along sinusoidal endothelial cells and on the microvillus extensions of hepatocytes into the space of Disse (23). Both sites are in intimate contact with nascent lipoproteins, which are secreted from the basal surface of hepatocytes into the space of Disse (56). Both sites are also near LDL receptors, which are expressed on the basal surface of hepatocytes (57) and on endothelial cells $(58,59)$. Some LpL was also found within hepatocytes (23), raising the speculative possibility of intracellular remodeling of nascent lipoproteins (cf. reference 60 ).

The physiologic importance of our findings also requires that $\mathrm{LpL}$ have similar effects on nascent lipoproteins from HepG 2 cells and from human livers. HepG2 cells secrete apo B primarily on a triglyceride-rich particle that has the same density as $\operatorname{LDL}(61,62)$, whereas human livers secrete primarily VLDL, with some "direct" secretion of $\operatorname{LDL}(63,64)$. All of 

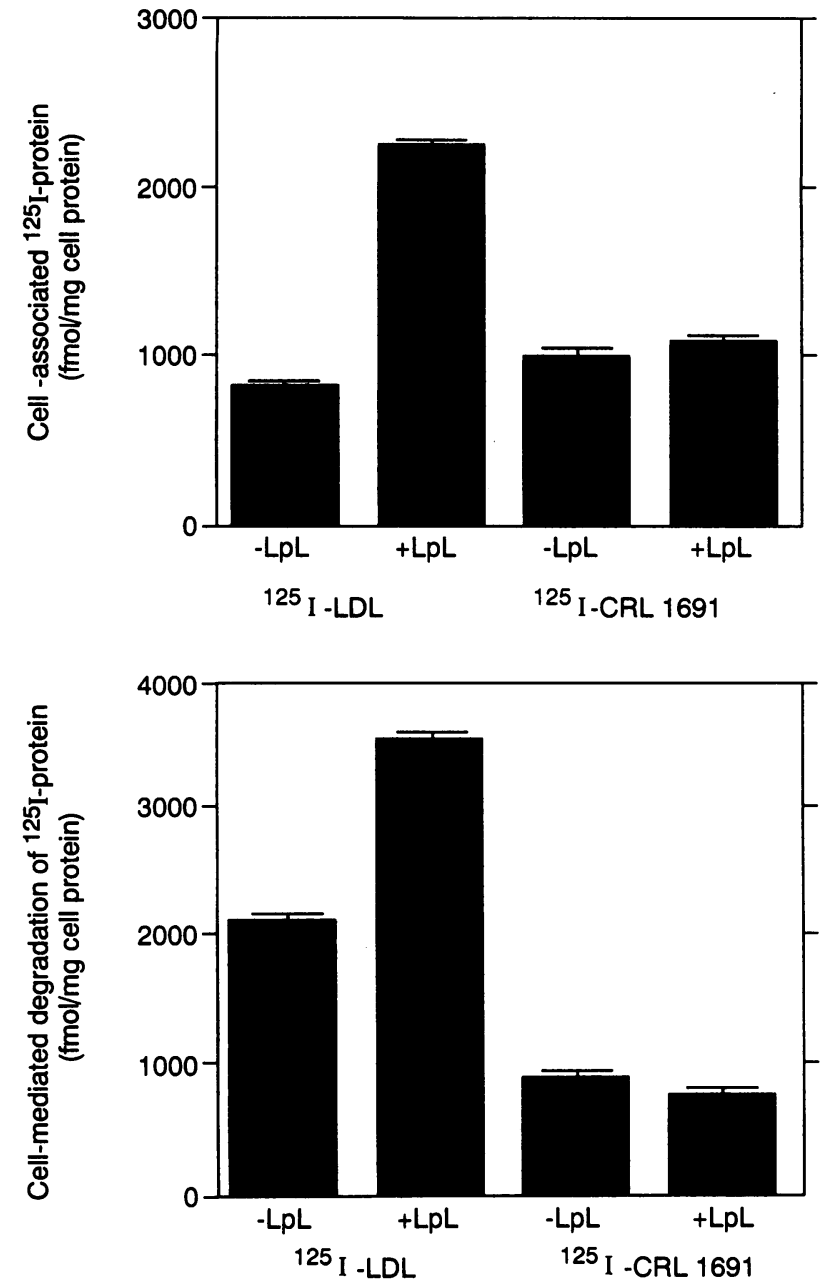

Figure 5. $\mathrm{LpL}$ increases uptake and degradation of mature plasma LDL, but not of a monoclonal anti-LDL receptor antibody (CRL 1691). Both ligands were radioiodinated, then separately incubated with HepG2 cells for $5 \mathrm{~h}$, with or without added $\mathrm{LpL}(0.640 \mathrm{U} / \mathrm{ml})$, as indicated. The top panel displays cellular uptake of ${ }^{125} \mathrm{I}$-protein. The bottom panel displays cell-specific degradation of ${ }^{125}$ I-protein. Means \pm SEM are shown, $n=4$. Uptake and degradation of ${ }^{125} \mathrm{I}-\mathrm{LDL}$ were significantly increased by $\operatorname{LpL}(P<0.001$ and $P<0.0001$, respectively). Uptake and degradation of ${ }^{125} \mathrm{I}-\mathrm{CRL} 1691$ were unaffected by LpL. Average cellular protein mass was $0.963 \mathrm{mg}$ per $35-\mathrm{mm}$ well.

these apo B-rich lipoproteins show large increases in their uptake by cells in the presence of LpL (references 5 and 6; Figs. 4 and 5). Because LpL has been shown to enhance cellular uptake of virtually every apo B-rich lipoprotein (5-10), we expect that net hepatic secretion of almost any type of apo B-rich particle could be reduced by $\mathrm{LpL}$ in vivo.

Partial LpL deficiency has been associated with some cases of familial combined hyperlipidemia $(25,26)$, a disease of hepatic apo B overproduction. It was hypothesized that the hyperlipidemia may arise in these patients because of impaired lipoprotein removal from the circulation (25), contrary to the usual finding of overproduction in kinetic studies (27). Our results suggest an alternative explanation: partial $\mathrm{LpL}$ deficiency would result in incomplete remodeling of nascent lipoproteins in and near the space of Disse and therefore cause impaired reuptake, which would appear in kinetic studies as overproduction (1). Thus, remodeling of nascent lipoproteins by $\mathrm{LpL}$ within the space of Disse to enhance reuptake may be a normal physiologic mechanism for regulating secretory output of apo B. It may also be subject to pharmacologic manipulation. For example, fibric acid compounds induce LpL (65-68) and decrease VLDL apo B secretion (69-72). To discern between net hepatic overproduction (1) and reduced peripheral clearance (25) as explanations for hyperlipidemia in patients with partial LpL deficiency, it will be important to measure their net hepatic apo $B$ production.

Lipoprotein lipase deficiency was reported to account for only one-third of cases of familial combined hyperlipidemia (26). The other two-thirds may have abnormalities in other factors known to affect lipoprotein binding to receptors (5-22) or in factors known to affect $\operatorname{LpL}(24,73)$. Of particular interest are cholesteryl ester transfer protein, which can change the neutral lipid composition of nascent lipoproteins (38) and might therefore alter receptor affinity $(11,14)$, and apoproteins CIII and AIV, which inhibit apo E-mediated binding $(20,21)$ and modulate LpL activity $(73,74)$. An association between apo AI restriction fragment length polymorphisms and familial combined hyperlipidemia has been reported $(75,76)$, which could reflect abnormalities in the closely linked genes for apo CIII and apo AIV (75-77).

The adaptive value of rapid remodeling and reuptake of nascent lipoproteins may, like other so-called futile cycles, involve regulation. Cholesterol enrichment of HepG2 cells results in increased secretion of apo B-rich particles $(2,3)$ through receptor suppression and inhibition of reuptake (2). Delivery of $\mathrm{LpL}$ and lipids to the liver during postprandial hyperlipidemia could alter hepatic output of apo B-rich lipoproteins through altered reuptake. Additionally, transfer and exchange of material onto nascent lipoproteins before reuptake may provide a means for importation of nutrients (cf. reference 38).

Overall, our findings indicate that reuptake of newly exported material can be affected by local, extracellular processing of the secreted ligand (cf. reference 2). There are other ligands besides apo B-rich lipoproteins that can be remodeled to alter cellular uptake. For example, if specific secreted glycoproteins are desialated within the space of Disse, re-uptake by the hepatic asialoglycoprotein receptor $(78,79)$ could occur, thereby affecting net output. Local reuptake, especially following local remodeling, may be a widespread phenomenon.

\section{Acknowledgments}

This work was supported by grant HL-38956 from the National Institutes of Health. During part of this work, Dr. Williams was a recipient of a Clinician-Scientist Award from the American Heart Association and E. R. Squibb \& Sons Co., with funds contributed in part by the American Heart Association-Southeastern Pennsylvania Affiliate.

This article is dedicated to the memory of Charles B. Hesler, Ph.D. (1954-1990), our able colleague and friend.

\section{References}

1. Williams, K. J., R. W. Brocia, K. Petrie, and T. L. Swenson. 1990. Lipoprotein lipase modulates net apolipoprotein-B output by HepG2 cells. Circulation. 82(Suppl. III):283. (Abstr.)

2. Williams, K. J., R. W. Brocia, and E. A. Fisher. 1990. The unstirred water layer as a site of control of apolipoprotein-B secretion. J. Biol. Chem. 265:1674116744.

3. Fuki, I. V., S. N. Preobrazhensky, A. Y. Misharin, N. G. Bushmakina, G. B. Menschikov, V. S. Repin, and R. S. Karpov. 1989. Effect of cell cholesterol content on apolipoprotein $B$ secretion and LDL receptor activity in the human hepatoma cell line, HepG2. Biochim. Biophys. Acta. 1001:235-238. 
4. Yedgar, S., D. B. Weinstein, W. Patsch, G. Schonfeld, F. E. Casanada, and D. Steinberg. 1982. Viscosity of culture medium as a regulator of synthesis and secretion of very low density lipoproteins by cultured hepatocytes. J. Biol. Chem. 257:2188-2192.

5. Aviram, M., E. L. Bierman, and A. Chait. Modification of low density lipoprotein by lipoprotein lipase or hepatic lipase induces enhanced uptake and cholesterol accumulation in cells. 1988. J. Biol. Chem. 263:15416-15422.

6. Catapano, A. L., S. H. Gianturco, P. K. J. Kinnunen, S. Eisenberg, A. M. Gotto, Jr., and L. C. Smith. 1979. Suppression of 3-hydroxy-3-methylglutarylCoA reductase by low density lipoproteins produced in vitro by lipoprotein lipase action on nonsuppressive very low density lipoproteins. J. Biol. Chem. 254:10071009.

7. Ishibashi, S., N. Yamada, H. Shimano, N. Mori, H. Mokuno, T. Gotohda, M. Kawakami, T. Murase, and F. Takaku. 1990. Apolipoprotein E and lipoprotein lipase secreted from human monocyte-derived macrophages modulate very low density lipoprotein uptake. J. Biol. Chem. 265:3040-3047.

8. Hui, D. Y., T. L. Innerarity, and R. W. Mahley. 1984. Defective hepatic lipoprotein receptor binding of $\beta$-very low density lipoproteins from type III hyperlipoproteinemic patients. Importance of apolipoprotein E. J. Biol. Chem. 259:860-869.

9. Ostlund-Lindqvist, A-M., S. Gustafson, P. Lindqvist, J. L. Witztum, and J. A. Little. 1983. Uptake and degradation of human chylomicrons by macrophages in culture. Role of lipoprotein lipase. Arteriosclerosis. 3:433-440.

10. Borensztajn, J., G. S. Getz, and T. J. Kotlar. 1988. Uptake of chylomicron remnants by the liver: further evidence for the modulating role of phospholipids. J. Lipid. Res. 29:1987-1096.

11. Aviram, M., S. Lund-Katz, M. C. Phillips, and A. Chait. 1988. The influence of the triglyceride content of low density lipoprotein on the interaction of apolipoprotein B-100 with cells. J. Biol. Chem. 263:16842-16848.

12. Borensztajn, J., T. J. Kotlar, and B. J. McNeill. 1980. Uptake of phospholipid-depleted chylomicrons by the perfused rat liver. Biochem. J. 192:845-851.

13. Kleinman, Y., E. S. Krul, M. Burnes, W. Aronson, B. Pfleger, and G. Schonfeld. 1988. Lipolysis of LDL with phospholipase $A_{2}$ alters the expression of selected apoB-100 epitopes and the interaction of LDL with cells. J. Lipid Res. 29:729-743.

14. Kinoshita, M., E. S. Krul, and G. Schonfeld. 1990. Modification of the core lipids of low density lipoproteins produces selective alterations in the expression of apoB-100 epitopes. J. Lipid Res. 31:701-708.

15. Zechner, R., H. Dieplinger, A. Roscher, and G. M. Kostner. 1984. The low-density-lipoprotein pathway of native and chemically modified low-density lipoproteins isolated from plasma incubated in vitro. Biochem. J. 224:569-576.

16. Ottnad, E., S. Parthasarathy, and D. Steinberg. 1990. Lysophosphatidylcholine increases the uptake and degradation of lipoproteins by mouse peritoneal macrophages. Circulation. 82(Suppl. III):561. (Abstr.)

17. Eisenberg, S., G. Friedman, and T. Vogei. 1988. Enhanced metabolism of normolipidemic human plasma very low density lipoprotein in cultured cells by exogenous apolipoprotein E-3. Arteriosclerosis. 8:480-487.

18. Kowal, R. C., J. Herz, K. H. Weisgraber, R. W. Mahley, M. S. Brown, and J. L. Goldstein. 1990. Opposing effects of apolipoproteins $E$ and $C$ on lipoprotein binding to low density lipoprotein receptor-related protein. J. Biol. Chem. 265:10771-10779.

19. Semenkovich, C. F., R. E. Ostlund, Jr., M. O. J. Olson, and J. W. Yang. 1990. A protein partially expressed on the surface of HepG2 cells that binds lipoproteins specifically is nucleolin. Biochemistry. 29:9708-9713.

20. Bisgaier, C. L., M. V. Siebenkas, and K. J. Williams. 1989. Effects of apolipoproteins A-IV and A-I on the uptake of phospholipid liposomes by hepatocytes. J. Biol. Chem. 264:862-866.

21. Windler, E., and R. J. Havel. 1985. Inhibitory effects of C apolipoproteins from rats and humans on the uptake of triglyceride-rich lipoproteins and their remnants by the perfused rat liver. J. Lipid Res. 26:556-565.

22. Weisgraber, K. H., R. W. Mahley, R. C. Kowal, J. Herz, J. L. Goldstein, and M. S. Brown. 1990. Apolipoprotein C-I modulates the interaction of apolipoprotein $E$ with $\beta$-migrating very low density lipoproteins ( $\beta$-VLDL) and inhibits binding of $\beta$-VLDL to low density lipoprotein receptor-related protein. J. Biol. Chem. 265:22453-22459.

23. Vilaró, S., I. Ramírez, G. Bengtsson-Olivecrona, T. Olivecrona, and M. Llobera. 1988. Lipoprotein lipase in liver. Release by heparin and immunocytochemical localization. Biochim. Biophys. Acta. 959:106-117.

24. Olivecrona, T., and G. Bengtsson-Olivecrona. 1987. Lipoprotein lipase from milk-the model enzyme in lipoprotein lipase research. In Lipoprotein Lipase. J. Borensztajn, editor. Evener Publishers, Inc., Chicago. 15-58.

25. Babirak, S. P., P-H. Iverius, W. Y. Fujimoto, and J. D. Brunzell. 1989. Detection and characterization of the heterozygote state for lipoprotein lipase deficiency. Arteriosclerosis. 9:326-334.

26. Babirak, S. P., and J. D. Brunzell. 1989. A subset of patients with familial combined hyperlipidemia have abnormal lipoprotein lipase. Circulation. 80(Suppl. II):79. (Abstr.)

27. Grundy, S. M., A. Chait, and J. D. Brunzell. 1987. Familial combined hyperlipidemia workshop. Arteriosclerosis. 7:203-207.

28. Posner, I., C-S. Wang, and W. J. McConathy. 1983. The comparative kinetics of soluble and heparin-Sepharose-immobilized bovine lipoprotein lipase. Arch. Biochem. Biophys. 226:306-316.

29. Laemmli, U. K. 1970. Cleavage of structural proteins during the assembly of the head of bacteriophage T4. Nature (Lond.). 227:680-685.

30. Peterson, J., T. Olivecrona, and G. Bengtsson-Olivecrona. 1985. Distribution of lipoprotein lipase and hepatic lipase between plasma and tissues: effect of hypertriglyceridemia. Biochim. Biophys. Acta. 837:262-270.

31. Belfrage, P., and M. Vaughan. 1969. Simple liquid-liquid partition system for isolation of labeled oleic acid from mixtures with glycerides. J. Lipid Res. 10:341-344.

32. Harlow, E., and D. Lane. 1988. Antibodies: A Laboratory Manual. Cold Spring Harbor Laboratory, Cold Spring Harbor, NY. 421-470.

33. Bisgaier, C. L., M. V. Siebenkas, M. L. Brown, A. Inazu, J. Koizumi, H Mabuchi, and A. R. Tall. 1991. Familial cholesteryl ester transfer protein deficiency is associated with triglyceride-rich low density lipoproteins containing cholesteryl esters of probable intracellular origin. J. Lipid Res. 32:21-33.

34. Egusa, G., D. W. Brady, S. M. Grundy, and B. V. Howard. 1983. Isopropanol precipitation method for the determination of apolipoprotein B specific activity and plasma concentrations during metabolic studies of very low density lipoprotein and low density lipoprotein apolipoprotein B. J. Lipid Res. 24:12611267.

35. Gottlieb, B. A., and J. B. Marsh. 1987. High density lipoprotein binding by rat Fu5AH hepatoma cells is not related to cholesterol content. Atherosclerosis. 67:251-259.

36. Markwell, M. A. K., S. M. Haas, L. L. Bieber, and N. E. Tolbert. 1978. A modification of the Lowry procedure to simplify protein determination in membrane and lipoprotein samples. Anal. Biochem. 87:206-210.

37. Goldstein, J. L., S. K. Basu, G. Y. Brunschede, and M. S. Brown. 1976 Release of low density lipoprotein from its cell surface receptor by sulfated glycosaminoglycans. Cell. 7:85-95.

38. Rinninger, F., and R. C. Pittman. 1989. Mechanism of the cholesteryl ester transfer protein-mediated uptake of high density lipoprotein cholesteryl esters by Hep G2 cells. J. Biol. Chem. 264:6111-6118.

39. Havel, R. J., H. A. Eder, and J. H. Bragdon. 1955. The distribution and chemical composition of ultracentrifually separated lipoproteins in human serum. J. Clin. Invest. 34:1345-1353.

40. Handlogten, M. E., L. Weissbach, and M. S. Kilberg. 1982. Heterogeneity of $\mathrm{Na}^{+}$-independent 2-aminobicylo-(2,2,1)-heptane-2-carboxylic acid and $\mathrm{L}$-leucine transport in isolated rat hepatocytes in primary culture. Biochem. Biophys. Res. Commun. 104:307-313.

41. Bilheimer, D. W., S. Eisenberg, and R. I. Levy. 1972. The metabolism of very low density lipoprotein proteins. I. Preliminary in vitro and in vivo observations. Biochim. Biophys. Acta. 260:212-221.

42. Goldstein, J. L., S. K. Basu, and M. S. Brown. 1983. Receptor-mediated endocytosis of low-density lipoprotein in cultured cells. Methods Enzymol. 98:241-260.

43. Beisiegel, U., W. J. Schneider, J. L. Goldstein, R. G. W. Anderson, and M. S. Brown. 1981. Monoclonal antibodies to the low density lipoprotein receptor as probes for study of receptor-mediated endocytosis and the genetics of familial hypercholesterolemia. J. Biol. Chem. 256:11923-11931.

44. van Driel, I. R., M. S. Brown, and J. L. Goldstein. 1989. Stoichiometric binding of low density lipoprotein (LDL) and monoclonal antibodies to LDL receptors in a solid phase assay. J. Biol. Chem. 264:9533-9538.

45. Masuno, H., T. Tsujita, H. Nakanishi, A. Yoshida, R. Fukunishi, and H. Okuda. 1984. Lipoprotein lipase-like activity in the liver of mice with Sarcoma 180. J. Lipid Res. 25:419-427.

46. Knobler, H., T. Chajek-Shaul, O. Stein, J. Etienne, and Y. Stein. 1984. Modulation of lipoprotein lipase in the intact rat by cholera toxin-an irreversible agonist of cyclic AMP. Biochim. Biophys. Acta. 795:363-371.

47. Testar, X., M. Llobera, and E. Herrera. 1985. Increase with starvation in the pregnant rat of the liver lipoprotein lipase activity. Biochem. Soc. Trans. 13:134.

48. Vilaró, S., M. Reina, I. Ramírez, and M. Llobera. 1986. Intralipid administration induces a lipoprotein lipase-like activity in the livers of starved adult rats. Biochem. J. 236:273-278.

49. Jenson G. L., D. L. Baly, P. M. Brannon, and A. Bensadoun. 1980. Synthesis and secretion of lipolytic enzymes by cultured chicken hepatocytes. $J$. Biol. Chem. 255:11141-11148.

50. Burgaya, F., J. Peinado, S. Vilaró, M. Llobera, and I. Ramírez. 1989. Lipoprotein lipase activity in neonatal-rat liver cell types. Biochem. J. 259:159166.

51. Semenkovich, C. F., S-H. Chen, M. Wims, C-C. Luo, W-H. Li, and L. Chan 1989. Lipoprotein lipase and hepatic lipase mRNA tissue specific expression, developmental regulation, and evolution. J. Lipid Res. 30:423-431.

52. Khoo, J. C., E. M. Mahoney, and J. L. Witztum. 1981. Secretion of lipoprotein lipase by macrophages in culture. J. Biol. Chem. 256:7105-7108.

53. Chait, A., P-H. Iverius, and J. D. Brunzell. 1982. Lipoprotein lipase secretion by human monocyte-derived macrophages. J. Clin. Invest. 69:490-493.

54. Wallinder, L., G. Bengtsson, and T. Olivecrona. 1979. Rapid removal to the liver of intravenously injected lipoprotein lipase. Biochim. Biophys. Acta. 575:166-173. 
55. Wallinder, L., J. Peterson, T. Olivecrona, and G. Bengtsson-Olivecrona. 1984. Hepatic and extrahepatic uptake of intravenously injected lipoprotein lipase. Biochim. Biophys. Acta. 795:513-524.

56. Hamilton, R. L., D. M. Regen, M. E. Gray, and V. S. LeQuire. 1967. Lipid transport in liver. I. Electron microscopic identification of very low density lipoproteins in perfused rat liver. Lab. Invest. 16:305-319.

57. Pathak, R. K., M. Yokode, R. E. Hammer, S. L. Hofmann, M. S. Brown, J. L. Goldstein, and R. G. W. Anderson. 1990. Tissue-specific sorting of the human LDL receptor in polarized epithelia of transgenic mice. J. Cell Biol. 111:347-359.

58. Vasile, E., M. Simionescu, and N. Simionescu. 1983. Visualization of the binding, endocytosis, and transcytosis of low-density lipoprotein in the arterial endothelium in situ. J. Cell Biol. 96:1677-1689.

59. Baker, D. P., B. J. Van Lenten, A. M. Fogelman, P. A. Edwards, C. Kean, and J. A. Berliner. 1984. LDL, scavenger, and $\beta$-VLDL receptors on aortic endothelial cells. Arteriosclerosis. 4:248-255.

60. Harrison, J. C., L. L. Swift, and V. S. LeQuire. 1988. Identification of lipoprotein-binding proteins in rat liver Golgi apparatus membranes. J. Lipid Res. 29:1439-1449.

61. Ellsworth, J. L., S. K. Erickson, and A. D. Cooper. 1986. Very low and low density lipoprotein synthesis and secretion by the human hepatoma cell line Hep-G2: effects of free fatty acid. J. Lipid Res. 27:858-874.

62. La Belle, M., M. R. McCall, R. M. Krauss, and T. M. Forte. 1990. Unique structural properties of apolipoprotein B in low-density lipoproteins produced by several human hepatoma-derived cell lines. Biochim. Biophys. Acta. 1046:288293.

63. Bennett, M. J., J. A. Cortner, P. M. Coates, D. R. Cryer, and J. B. Marsh. 1989. Evidence for direct synthesis of low density lipoprotein in normal and hyperlipidemic humans using stable isotopes. Circulation. 80(Suppl. II):383. (Abstr.)

64. Arad, Y., R. Ramakrishnan, and H. N. Ginsberg. 1990. Lovastatin therapy reduces low density lipoprotein apoB levels in subjects with combined hyperlipidemia by reducing the production of apoB-containing lipoproteins: implications for the pathophysiology of apoB production. J. Lipid Res. 31:567-582.

65. Saku, K., P. S. Gartside, B. A. Hynd, and M. L. Kashyap. 1985. Mechanism of action of Gemfibrozil on lipoprotein metabolism. J. Clin. Invest. 75:1702-1712.

66. Grundy, S. M., and G. L. Vega. 1987. Fibric acids: effects on lipids and lipoprotein metabolism. Am. J. Med. 83(Suppl. 5B):9-20.

67. Weisweiler, P. 1989. Low-dose colestipol plus fenofibrate: effects on plasma lipoproteins, lecithin: cholesterol acyltransferase, and postheparin lipases in familial hypercholesterolemia. Metab. Clin. Exp. 38:271-274.

68. Vessby, B., and H. Lithell. 1990. Interruption of long-term lipid-lowering treatment with benzafibrate in hypertriglyceridaemic patients: effects on lipoprotein composition, lipase activities and the plasma fatty acid spectrum. Atherosclerosis. 82:137-143.

69. Kissebah, A. H., S. Alfarsi, P. W. Adams, M. Seed, J. Folkard, and V. Wynn. 1976. Transport kinetics of plasma free fatty acid, very low density lipoprotein triglycerides and apoprotein in patients with endogenous hypertriglyceridemia. Effects of 2,2-dimethyl,5(2,5-xylyloxy) valeric acid therapy. Atherosclerosis. 24:199-218.

70. Turner, P. R., C. Cortese, R. Wootton, C. Marenah, N. E. Miller, and B. Lewis. 1985. Plasma apolipoprotein B metabolism in familial type III dysbetalipoproteinaemia. Eur. J. Clin. Invest. 15:100-112.

71. Packard, C. J., R. J. Clegg, M. H. Dominiczak, A. R. Lorimer, and J. Shepherd. 1986. Effects of bezafibrate on apolipoprotein B metabolism in type III hyperlipoproteinemic subjects. J. Lipid Res. 27:930-938.

72. Petit, D., M. T. Bonnefis, C. Rey, and R. Infante. 1988. Effects of ciprofibrate and fenofibrate on liver lipids and lipoprotein synthesis in normo- and hyperlipidemic rats. Atherosclerosis. 74:215-225.

73. Goldberg, I. J., C. A. Scheraldi, L. Y. Yacoub, U. Saxena, and C. L. Bisgaier. 1990. Lipoprotein apoC-II activation of lipoprotein lipase: modulation by apolipoprotein A-IV. J. Biol. Chem. 265:4266-4272.

74. Jackson, R. L., S. Tajima, T. Yamamura, S. Yokoyama, and A. Yamamoto. 1986. Comparison of apolipoprotein C-II-deficient triacylglycerol-rich lipoproteins and trioleoylglycerol/phosphatidylcholine-stabilized particles as substrates for lipoprotein lipase. Biochim. Biophys. Acta. 875:211-219.

75. Hayden, M. R., H. Kirk, C. Clark, J. Frohlich, S. Rabkin, R. McLeod, and J. Hewitt. 1987. DNA polymorphisms in and around the apo-A1-CIII genes and genetic hyperlipidemias. Am. J. Hum. Genet. 40:421-430.

76. Wojciechowski, A. P., M. Farrall, P. Cullen, T. M. E. Wilson, J. D. Bayliss, B. Farren, B. A. Griffin, M. J. Caslake, C. J. Packard, J. Shepherd, R. Thakker, and J. Scott. 1991. Familial combined hyperlipidaemia linked to the apolipoprotein AI-CIII-AIV gene cluster on chromosome 11q23-q24. Nature (Lond.). 349:161-164.

77. Fisher, E. A., P. M. Coates, and J. A. Cortner. 1989. Gene polymorphisms and variability of human apolipoproteins. Annu. Rev. Nutr. 9:139-160.

78. Ashwell, G., and A. G. Morell. 1974. The role of surface carbohydrates in the hepatic recognition and transport of circulating glycoproteins. Adv. Enzymol. 41:99-128.

79. A. L. Schwartz. 1984. The hepatic asialoglycoprotein receptor. CRC Crit. Rev. Biochem. 16:207-233. 